\title{
Liberated Africans, Slaves, and Convict Labor in the Construction of Rio de Janeiro's Casa de Correção: Atlantic Labor Regimes and Confinement in Brazil's Port City*
}

\author{
MARTINE JEAN \\ Weatherhead Research Cluster on Global Transformations \\ 1727 Cambridge Street, Cambridge, MA 02138 , USA \\ E-mail: mjean@wcfia.harvard.edu
}

\begin{abstract}
From i 834 to I 850 , Latin America's first penitentiary, the Casa de Correção in Rio de Janeiro, was a construction site where slaves, "liberated Africans", convicts, and unfree workers interacted daily, forged identities, and deployed resistance strategies against the pressures of confinement and the demands of Brazil's eclectic labor regimes. This article examines the utilization of this motley crew of workers, the interactions among "liberated Africans", slaves, and convict laborers, and the government's intervention between I 848 and I 850 to restrict slave labor at the prison in favor of free waged workers. It asserts that the abolition of the slave trade in 1850 and the subsequent inauguration of the penitentiary augured profound changes in Rio's labor landscape, from a predominantly unfree to a free wage labor force.
\end{abstract}

In his I 849 annual report to the Brazilian parliament, Justice Minister Eusébio de Queiroz Mattoso da Camara observed that most of the workers employed in the construction of Rio de Janeiro's penitentiary, the Casa de Correção, were slaves, and he concluded that it would be less expensive for the government to hire free laborers to complete it. Queiroz's main concern was that, after nearly sixteen years of construction, the Casa de Correção was only halfway done. Only one of its planned four pavilions was near completion. Meanwhile, Rio's civil jail, the Aljube, stood as a "shameful anachronism" in the Brazilian capital, where convicted criminals

\footnotetext{
* I am grateful to the editors and contributing authors of this Special Issue. I would also like to thank the participants and organizers of the "Free and Unfree Labor in Atlantic and Indian Ocean Port Cities (c.1700-1850)" conference and workshop held at the University of Pittsburgh in May 2016 and May 2017.
} 
shared cells with other detainees awaiting formal arraignment. ${ }^{\mathrm{I}}$ Queiroz emphasized the necessity to inaugurate the penitentiary to modernize Rio's penal system.

This article analyzes the utilization of a motley crew of slaves, convicts, liberated Africans, and free laborers to build the Casa de Correção between I 833 and I 850 . It probes a crucial nexus point centered on Rio's significance as Brazil's preeminent commercial port city, where transformations in the labor regimes of the Atlantic from unfree to free labor reverberated. It argues that the deployment of slaves, convicts, liberated Africans, and unfree workers to build the Casa de Correção demonstrates that until the first half of the nineteenth century the boundaries between free and unfree labor were very porous in the Brazilian capital. The significance of slaves in the city's population and the availability of pauperized legally free workers allowed the authorities to constantly combine free and unfree laborers to clean Rio's streets and to build public infrastructures associated with social control and progress, such as repairing public fountains, aqueducts, and the seawall in the harbor. The permutation of labor arrangements in public works allowed legally free and enslaved laborers to interact daily in the capital. The abolition of the slave trade in I850 engendered a politics to transform the Casa de Correção into a site for re-articulating the geography of free and unfree labor in Rio through a hardening of the distinctions between salaried slaves and legally free wage workers. Brazilian authorities intervened over time to restrict bonded labor to plantation agriculture and maintained various forms of free and unfree labor, including contract labor, apprenticeship, and prison reformatory work, on Brazil's coastline, particularly in Rio, the capital.

The penitentiary belongs to Brazil's postcolonial nation-building process, which rested on concretizing the country's aspiration to modernity through prison reforms and engendering a law-abiding free working-class citizenry to abate the dependency on slave labor. ${ }^{2}$ In this way, Brazil participated in two interrelated ideological shifts in the Atlantic World that restricted freedom for unruly and criminal social elements of the poor through confinement

I. Brasil, Relatório do ministério da justiça do anno I849, I $A$ apresentado a assembléa geral legislativa na Iera sessão da 8 a legislativa em 1850 (Rio de Janeiro, I 850 ), pp. 50-53.

2. Carlos Aguirre, "Prisons and Prisoners in Modernising Latin America (1800-1940)", in Frank Dikötter and Ian Brown (eds), Cultures of Confinement: A History of the Prison in Africa, Asia, and Latin America (Ithaca, NY, 2007), pp. I4-54. Ricardo D. Salvatore and Carlos Aguirre, "The Birth of the Penitentiary in Latin America: Toward an Interpretive Social History of Prisons", in Ricardo D. Salvatore and Carlos Aguirre (eds), The Birth of the Penitentiary in Latin America: Essays on Criminology, Prison Reform, and Social Control, I830-1940 (Austin, TX, 1996), pp. I-43; Martine Jean, “'A Storehouse of Prisoners': Rio de Janeiro's Correction House (Casa de Correção and the Birth of the Penitentiary in Brazil, I 830-1906", Atlantic Studies: Global Currents, I4:2 (2017), pp. 2 I6-242. 
while advocating the gradual abolition of slavery. ${ }^{3}$ As Clare Anderson's contribution to this Special Issue argues, the abolition of slavery in the Atlantic engendered the spread of penal transportation and convictism in the Indian Ocean as part of the "circuit of repression and coerced labor extraction" that defined the global economy. ${ }^{4}$ That Brazil was a major recipient of African slaves through the traffic rendered its reception and implementation of penal reform ideas and anti-slavery problematic. Brazilian port cities, foremost Rio de Janeiro, became the experimenting ground for the deployment of these concepts because of their significance as international ports of trade and urban centers with a cosmopolitan working class that included African slaves, free people of color, and sailors of multinational origins, foreign immigrants, soldiers, and skilled artisans. Rio shared this pattern with other port cities in the Americas and seaports in the Atlantic and Indian Ocean. ${ }^{5}$

As an Atlantic port city, Rio de Janeiro connected Brazil's hinterland with commercial networks that integrated the African coast to the Americas through the slave trade and to Europe through export-driven agriculture (Figure I). The city was in the center of the transformation of slavery in the Atlantic, a process that Dale Tomich conceptualized as a Second Slavery, evidenced by its "partial relocation" and the "invention of new forms of unfree labor" that saw the institution gaining ground in Brazil, Cuba, and the US South while disintegrating in the British and French Caribbean in the nineteenth century. ${ }^{6}$ Between I 83 I and I855, an estimated 7I 8,000 slaves entered Brazil, or equivalent to twenty per cent of the total slave traffic during its three centuries of existence. ${ }^{7}$ The majority of the

3. On anti-slavery and the penitentiary, see Diana Paton, No Bond But the Law: Punishment, Race, and Gender in Jamaican State Formation, $1780-1870$ (Durham, NC, 2004), p. 5; David B. Davis, The Problem of Slavery in the Age of Revolution, I770-I 823 (Ithaca, NY, 1975), p. 242; Melanie Newton, "Freedom's Prisons: Incarceration, Emancipation, and Modernity", in No Bond But the Law", Small Axe, I 5:I (201 I), pp. 164-175; Thomas Holt, The Problem of Freedom: Race, Labor, and Politics in Jamaica and Britain, $1832-1938$ (Baltimore, MD, 1992), pp. 21-53; Peter Beattie, Punishment in Paradise: Race, Slavery, Human Rights, and a Nineteenth-Century Brazilian Penal Colony (Durham, NC, 2015), pp. 200-226.

4. See Clare Anderson, "Convicts, Commodities, and Connections", abstract, in this Special Issue.

5. David Montgomery, "The Working Classes of the Pre-Industrial American City, $1780-1830$ ", Labor History, 9:I (1968), pp. 3-22; Seth Rockman, Scraping By: Wage Labor, Slavery, and Survival in Early Baltimore (Baltimore, MD, 2009).

6. Dale W. Tomich, Through the Prism of Slavery: Labor, Capital, and World Economy (Lanham, MD, 2004), pp. 56-71; Rafael de Bivar Marquese and Tâmis Peixoto Parron, "Internacional escravista: a política da segunda Escravidão", Topoi, I 2 (July-December 20I I), pp 97-I 17; Sidney Chalhoub, "The Politics of Ambiguity: Conditional Manumission, Labor Contracts, and Slave Emancipation in Brazil (1850s-1888)", International Review of Social History, 60:2 (2015), pp. I6I-162.

7. See: http://www.slavevoyages.org/estimates/zbsnLoVK; last accessed 26 October 2018; Joseph C. Miller, Way of Death: Merchant Capitalism and the Angolan Slave Trade, 1730I 830 (Madison, WI, I988), pp. 455-458; Roquinaldo do Amaral, "Brasil e Angola no tráfico 


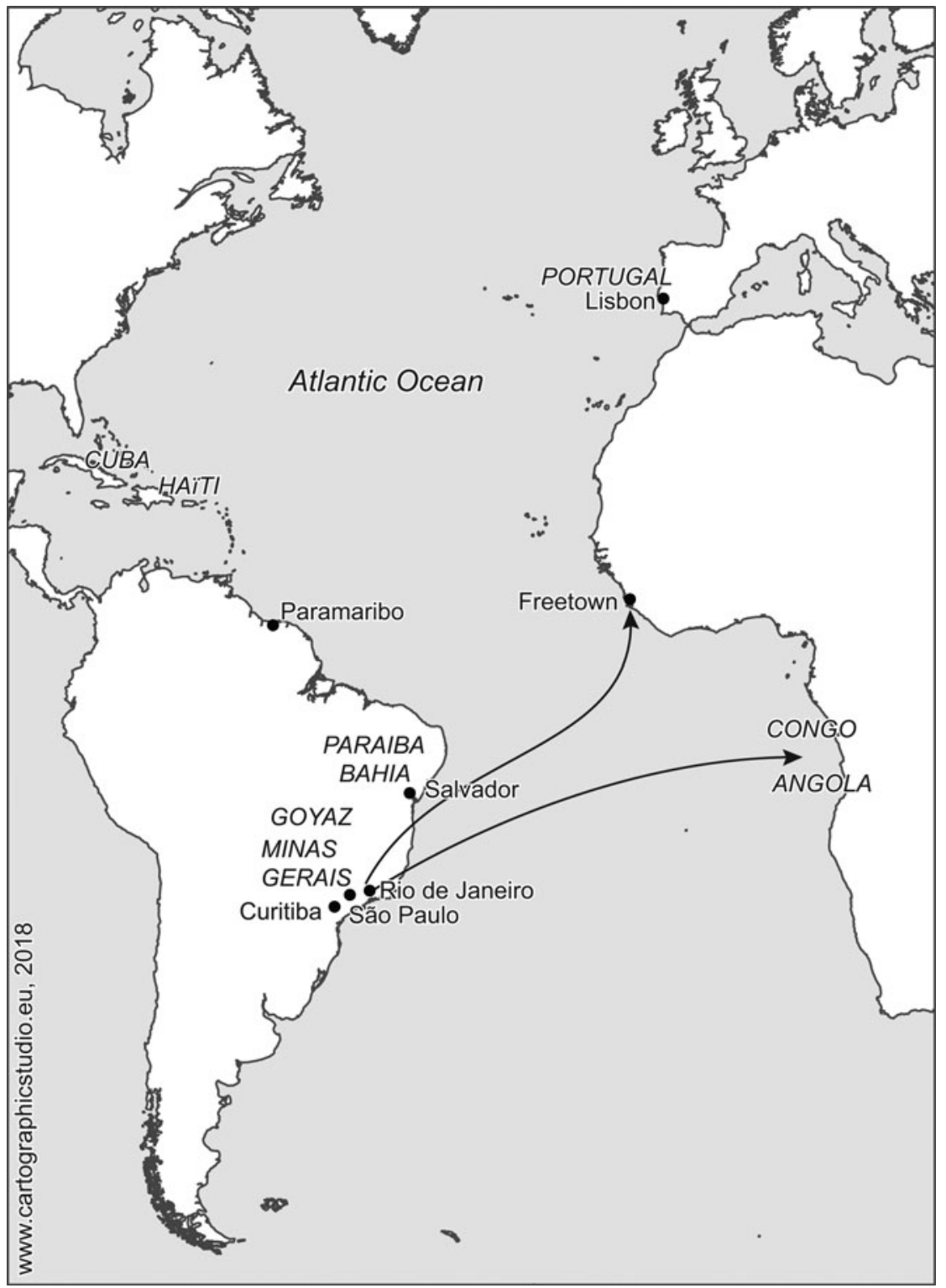

Figure I. Some of the major port cities with which Rio de Janeiro was linked in the nineteenth century through the slave trade and commerce in colonial products.

ilegal de escravos, I830-1860", in José Flávio Sombra Saraiva (ed.), Angola e Brasil nas rotas do Atlântico Sul (Rio de Janeiro, 1999), pp. I43-193. 
enslaved were destined to work in the prosperous coffee plantations of Brazil's central-south region, notably the Vale do Paraiba, or Paraiba Valley. The increased volume of the traffic through Rio transformed the city demographically, but also created a local economy around the port that provided the goods and services that transient sailors depended upon for survival. As Melina Teubner's contribution to this Special Issue highlights, food-selling women played an important role in the informal economy around Rio's port by feeding the multitude of workers, sailors, waged slaves, and fugitives who worked in the city or aboard the slave ships that tied Rio to other domestic seaports, the African coast, and Europe. Mule traders from Rio's hinterland depended on street commerce to sustain them while passing through the capital. ${ }^{8}$ Police surveillance was particularly necessary to control the circulation of slaves and freedmen in the city, and the availability of prisons was a fundamental aspect of regulating Rio's economic and social life. ${ }^{9}$ Following the abolition of the traffic in I 850 , the internal slave trade relocated slaves from north-eastern sugar plantations to the coffee economy of the central-south region. Rio served as an important corridor from whence these slaves were distributed to the Paraiba Valley. ${ }^{10}$

The Casa de Correção was fundamental in regulating this process, whether through the imprisonment and flogging of fugitive slaves, the custody of enslaved men and women in the process of being sold out of the city, or the detention of vagrants and beggars who challenged the new geography of labor unfolding. ${ }^{\text {II }}$ Most of Rio's slaves originated from Angola and the Congo in the nineteenth-century and the Casa de Correção housed a microcosm of that population as a result of the prohibition of the illegal slave trade. In early July I 834, the Casa de Correção received 249 emancipated Africans from the Duquesa de Bragança, and i 8 liberated Africans from the Patacho Santo Antonio, two vessels which were condemned in July I 834 . The police

8. Melina Teubner, "Street Food, Urban Space, and Gender", in this Special Issue; for a comparative study of food selling in Brazil's seaport, see Richard Graham, Feeding the City: From Street Market to Liberal Reform in Salvador, Brazil, I780-I860 (Austin, TX, 2010).

9. Leila Mezan Algranti, "Slave Crimes: The Use of Police Power to Control the Slave Population of Rio de Janeiro", Luso-Brazilian Review, 25:1 (1988), pp. 27-48; Thomas Holloway, Policing Rio de Janeiro: Repression and Resistance in a Igth-Century City (Stanford, CA, 1993).

Io. Robert Slenes, "The Brazilian Internal Slave Trade, I850-I 888: Regional Economies, Slave Experience, and the Politics of a Peculiar Market", in Walter Johnson (ed.), The Chattel Principle: Internal Slave Trades in the Americas (New Haven, CT, 2004), pp. 325-370; Herbert Klein, "The Internal Slave Trade in Nineteenth-Century Brazil: A Study of Slave Importations into Rio de Janeiro in I 852", Hispanic American Historical Review, 51:4 (I97I), pp. $567-585$.

I I. Tom Brass and Marcel van der Linden (eds), Free and Unfree Labour: The Debate Continues (New York, 1997); Marcel van der Linden, Workers of the World: Essays Toward a Global Labor History (Leiden, 2008). 
also sent illegally enslaved Africans from land seizures to the prison. Slaves aboard the Santo Antonio were all identified as from Gabon in Congo while the Duquesa de Bragança's Africans were a mixed ethnicity from Benguella and Angola. As a result, the Africans did not experience their confinement aboard the ship and the Casa de Correção in isolation, and could converse among themselves and with other slaves.

\section{THE POLITICS OF BUILDING THE PENITENTIARY IN POSTCOLONIAL BRAZIL}

The impetus to build the Casa de Correção originated from Brazil's independence from Portugal in I 822 under a constitutional monarchy, followed by the adoption of a criminal code in 1830 . The code called for prisons to be "hygienic, secure, and well-organized", and established confinement as punishment for most crimes through "prison with work", "simple imprisonment", and galés, or hard labor in public works in fetters (Figure 2). ${ }^{\mathrm{I}}$ "Prison with work" reflected the influence of liberal penal ideas, which hinged on the view that confinement was a site to reform criminals through compulsory labor and silence. Through its adoption, Brazil embraced a positive view of work as having the capacity to reform criminals into citizens.

Subsequent decrees and police regulations empowered local justices of the peace to investigate and issue sentences for "public crimes" such as vagrancy and the unlicensed carrying of pistols, daggers, and other perforating instruments. Participating in riots or the illegal assembly of groups of five or more could lead to a "prison with work" sentence of one to six months. ${ }^{\mathrm{I}}{ }^{3}$ Justices of the peace such as João José da Cunha of the Sacramento district utilized this new authority to call on lawful citizens to aid the police to identify "vagrants and idlers" who had broken into various houses of the parish in I 832. ${ }^{I 4} \mathrm{~A}$ year earlier, in I $83 \mathrm{I}$, a deputy justice of the peace calmed the public about the lack of repression against vagrants by assuring them that he had recently sentenced "eleven vagrants to 24 days of prison with labor" at the navy yard. He had also previously sent ten individuals to the army arsenal after they "approached him alleging that they could not find an occupation". Is "Prison with labor" sentences were applied to convicts who disturbed the peace, constituted a threat to private property, and committed

I2. Evaristo de Morães, Prisões e instituições penitenciarias no Brasil (Rio de Janeiro, 1923), pp. I-I5; on Brazilian liberalism, see Thomas Flory, Judge and Jury in Imperial Brazil, 1808-I87I: Social Control and Political Stability in the New State (Austin, TX, I981), pp. 50-64. 13. See Law of 26 October I83 I, published in Diário do Rio de Janeiro, 3 November I 33 I. I4. Juiz de Paz, João José da Cunha, Freguesia do Sacramento, 28 February 1 832, in Diário do Rio de Janeiro, 29 February i 832.

I 5. Juiz de Paz, Saturnino de Souza e Oliveira, 6 August i83 I, in Diário do Rio de Janeiro, 8 August I83I. 


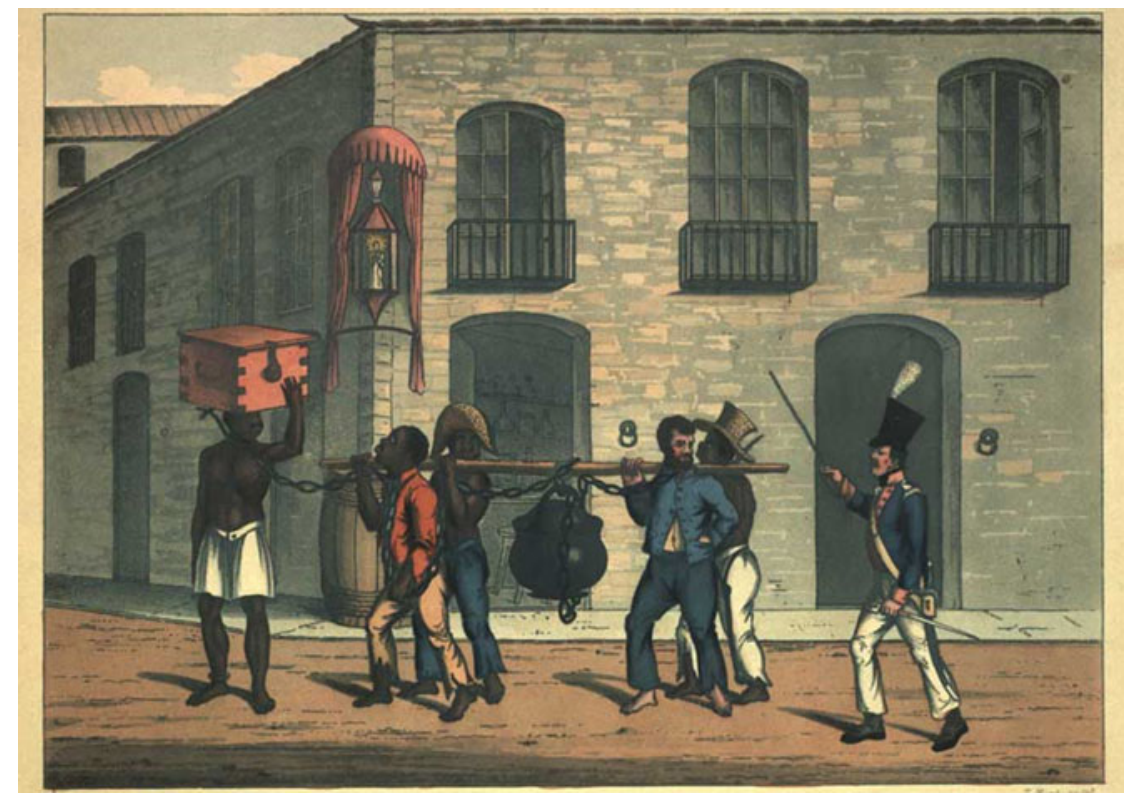

Figure 2. T. Hunt, "Criminals Carrying Provisions to the Prison", London, I 822. Biblioteca Nacional, Rio de Janeiro, available at: http://acervo.bndigital.bn.br/sophia/index.asp? codigo_sophia $=2807$; last accessed 26 October 2018.

homicide. They were individuals of free legal status in Brazilian society. For example, José Antonio da Conceição, born in Lisbon, was punished with two years and a month of "prison with labor" in 1838 for stealing slaves. ${ }^{16}$ By contrast, Joaquim Mina, a West African slave from the Mina coast, was sentenced to 400 lashes for a similar offence. ${ }^{17}$

Before the completion of the penitentiary, individuals who were sentenced to "prison with work" joined the pool of unfree workers whose labor power was utilized by public institutions in small- and large-scale work associated with modernizing the city, such as road building, constructing the seawall at Snakes Island, or repairing municipal fountains. The ethnic and racial profile of this dangerous class reflected Rio's importance as an international port city with slave and legally free workers of color as well as European

I6. Jury Tribunal, extraordinary session of April I838, in Diário do Rio de Janeiro, 25 May I 838 .

17. Jury Tribunal, session of 3 I January I 838 , in Diário do Rio de Janeiro, 5 February I 838 ; in prison records and other official sources, slaves' "surnames" were attributed based on their African or Brazilian ancestry, which also indicated their place of birth or port of purchase, color, status, and provincial origins at times. See Mary Karasch, Slave Life in Rio de Janeiro, I808-I850 (Princeton, NJ, 1987), pp. 3-28. 
immigrants. In late December I 833, a group of prisoners who escaped from their work site at the navy arsenal with the help of a prison guard included three Brazilians, a freed person of color - pardo - chastised with hard labor in perpetuity for murder, two other pardos - one an ex-soldier convicted of desertion and another sentenced for robbery - and a thirty-six-year-old Prussian skilled in saddlery who was sentenced to "prison with labor". They were all reduced to unfreedom, despite their differing legal status outside of confinement and coerced labor.

Hard-labor sentences were designed to chastise slave criminals, especially those who committed mastercide or fomented rebellion. ${ }^{18}$ Galés - hard labor in public works in fetters - also applied to free people who committed property crimes such as slave thefts and counterfeiting, activities which attacked the economic basis of society. In I 833, a list of galé convicts who had completed their sentences included three free individuals, one of whom was punished for theft. Another convict was chastised with two years of galés for stealing slaves, while the last one was punished to four years of hard labor for highway robbery. ${ }^{19}$ In February 1834, from among ten galé convicts who had escaped from the dungeon at Snakes Island, four were white, including two Portuguese immigrants, two were pardos, and one of the fugitives was a West Central African slave named João Benguella, who had been condemned to ten years of forced labor at the dike for homicide. ${ }^{20}$ The convicts originated from the north-east and south-east of Brazil. Soldiers like Manoel Gomes Pimenta, a white man from north-east Brazil, and Paulino dos Santos, a free person of color from Rio, often found themselves among galé convicts for desertion and insubordination in the army or the navy, which were important social control institutions that thrived on the recruitment of coerced workers, especially free people of color. ${ }^{21}$ Galé inmates were therefore a heterogeneous group that included mostly slaves but also some free offenders. They included Brazilian, European, and

I 8. João Luiz Ribeiro, "No meio das galinhas as baratas não têm razão": a lei de Io de junho de I835, os escravos e a pena de morte no império Brasileiro (Rio de Janeiro, 2005), pp. 22-38; Alexandra K. Brown, “'A Black Mark on Our Legislation': Slavery, Punishment, and the Politics of Death in Nineteenth-Century Brazil”, Luso-Brazilian Review, 37:2 (2000), pp. 95I2I; Peter Beattie, "'Born Under the Cruel Rigor of Captivity, the Supplicant Left it Unexpectedly by Committing a Crime"”: Categorizing and Punishing Slave Convicts in Brazil, I 830-1897", The Americas, 66:I (2009), pp. I I-55.

19. Correio Official, 30 October i 833 .

20. "Repartição da Polícia", in Correio Official, 24 February i 834.

21. Peter Beattie, "Conscription Versus Penal Servitude: Army Reform's Influence on the Brazilian State's Management of Social Control, 1870-1930", Journal of Social History, 32:4 (1999), pp. 847-878; Zachary R. Morgan, Legacy of the Lash: Race and Corporal Punishment in the Brazilian Navy and the Atlantic World (Bloomington, IN, 2014), pp. 50-52; Patricia Ann Aufderheide, "Order and Violence: Social Deviance and Social Control in Brazil, I780I 840 ” (Ph.D. dissertation, University of Minnesota, I975), pp. I4-I9; see Megan Thomas’s contribution on military labor in the Special Issue. 
African-born, as well as legally enslaved and free persons. Convicts worked manacled to one another at their ankle or neck, which was the condition under which chained gangs of slaves carried water to various venues in Rio. If one were not a slave, to be chastised to galés and to "prison with work" before the advent of the penitentiary constituted a reduction to the status of a judicial slave.

\section{URBAN SLAVERY AND PRISON LABOR IN NINETEENTH-CENTURY RIO}

The prison population reflected Rio's multi-ethnic inhabitants and its significance as Brazil's preeminent commercial seaport in the nineteenth century. With a significant urban slave population and an extensive harbor that linked its agrarian hinterland to European commercial centers and the African Slave Coast, Rio was a city marked by the interaction of slave and free workers. As other port cities in the Atlantic and Indian Ocean, Rio had been "a crucial component of European expansion" since the sixteenth century and a "fulcrum of European activity" by the nineteenth century. ${ }^{22}$ Its economic life depended on the manual labor performed by thousands of Brazilian and African slaves, enslaved female domestic workers, laundresses, cooks, sailors, Portuguese cashiers, porters as well as white civil servants, impoverished policemen, and soldiers.

Rio became a center of the Lusophone Empire between 1763 and I808, when gold and diamond mines were discovered in its interior and the Portuguese crown relocated to Brazil. Thousands of impoverished Portuguese immigrants and Brazilian north-easterners flocked to the mining region through Rio's harbor. ${ }^{23}$ The volume of the traffic increased, resulting in the slave population as a proportion of the total population increasing from 34.6 per cent in 1799 to 45.6 per cent in I $82 \mathrm{I}$ (Table I). Fifty per cent of enslaved Africans sold to Brazil between I 808 and I82I passed through Rio's port. ${ }^{24}$ In I 808, an estimated i 5,000 Portuguese courtiers migrated to the city, which created a housing crisis and a boom in construction. The crown liberated Rio's port for free trade, leading to hundreds of British commercial agents establishing residences in the city, along with Frenchmen and Germans. French tailors owned fashionable boutiques on

22. Franklin Knight and Peggy Liss (eds), Atlantic Port Cities: Economy, Culture, and Society in the Atlantic World, I650-I850 (Knoxville, TN, I991), pp. I-7.

23. A.J.R. Russell-Wood, "Ports of Colonial Brazil", in ibid., p. 20I; Mary Karasch, "Rio de Janeiro: From Colonial Town to Imperial Capital (I808-I 850)", in Robert J. Ross and Gerard J. Telkamp (eds), Colonial Cities: Essays on Urbanism in a Colonial Context (Dordrecht, I985), pp. I39-I4I.

24. Karasch, "Rio de Janeiro: From Colonial Town to Imperial Capital", pp. I39-I4I. 
Table I. Composition of the population of Rio de Janeiro, I799-I849 (\%).

\begin{tabular}{lllccr}
\hline & 1799 & $1821^{*}$ & $1834^{*}$ & $1838^{*}$ & 1849 \\
\hline Slaves & 34.6 & 45.6 & 44.4 & 38.2 & 38.3 \\
Free & 45.1 & 54.4 & 33.8 & 52.3 & 38.9 \\
Free people of color & 20.3 & - & 14.9 & - & 5.2 \\
Foreigners & - & - & 6.9 & 9.5 & 17.6 \\
\hline
\end{tabular}

Sources: Karasch, Slave Life in Rio de Janeiro, pp. 62-66, and Yedda Linhares and Barbara Lévy, "Aspectors da história demográfica e social do Rio de Janeiro (18081889)", in L'Histoire Quantitative du Brésil de 1800 à 1930. Colloques Internationaux du Centre National de la Recherche Scientifique, no. 543 (Paris, 1973), pp. 128-130. The 1821 censuses included free people and freed persons as a single group. The 1834 and 1838 censuses undercounted the city's slave population as well as the number of foreigners.

Ouvidor Street. Portuguese artisans and small businessmen established their shops in St Peter's Street. ${ }^{25}$ Much more diluted in the population were the Germans, Chinese, Prussians, South Americans, and North Americans who passed through the city. Foreigners represented 9.5 per cent of the city's population by 1838 , which undercounted their presence in the city. Historian Mary Karasch estimated that Rio's slaves likely represented 56.7 per cent of the city's total population in 1834 and 5 I.6 per cent in 1838 based on studies of estimated numbers of slaves owned per household. ${ }^{26}$ The drop in the slave population in 1849 reflected the increase in the number of European immigrants in the city. The city's diverse population was well represented in jail records, and after I 850 the number of foreigners in the central police station jail regularly surpassed the number of Brazilian nationals there. ${ }^{27}$

Rio's slaves operated in a wage labor market that was inserted in a slave society. There were two kinds of wage-earning slaves in the city: slaves-for-hire - escravos ao ganho - who, in agreement with their owner, sold their services after fulfilling their obligation to their masters, to whom they paid an agreed portion of their earnings, and leased slaves escravo de aluguel - whose services were rented out by their owners to an

25. Zephyr Frank, "Layers, Flows and Intersections: Jeronymo José de Mello and Artisan Life in Rio de Janeiro, i 840s-I 880s", Journal of Social History, 41:2 (2007), pp. 307-328.

26. Karasch, Slave Life in Rio de Janeiro, p. 6r. The author estimated that there were 3.6 slaves owned per household.

27. Criminal statistics became more organized after i 850 . For example, in I $857-1858$, of 6,495 detainees admitted to the city jail, 4,956 were foreigners; see the annual reports of Chief of Police of Rio de Janeiro published in the annex to Brasil, Relatório do ministério da justiça, I 825 -1928, available at: http://ddsnext.crl.edu/brazil; last accessed 26 October 2018. 
employer. ${ }^{28}$ Slaves-for-hire worked on short-term commissions and exerted more control over their meager earnings, while leased slaves did not directly participate in the exchange between their employers and their owner. Slaves toiled as seamstresses, porters, peddlers, barbers, carpenters, masons, and were the bedrock of Rio's economic life. Many leased slaves were owned or hired by foreign skilled artisans, who possessed twenty per cent of the city's slave population. ${ }^{29}$ Rio's slaves were ethnically diverse and divided between Brazilian-born slaves known as Crioulo and African-born slaves, who represented sixty-five per cent of the urban slave population. The majority originated from West Central Africa. ${ }^{3 \circ}$

Rio also disposed of a substantial free poor class who constituted a "reserve labor force". ${ }^{\text {I }}$ They were a subset of the "Atlantic proletariat", which were temporarily employed and often did the work of slaves. ${ }^{32}$ The city's free poor were manumitted slaves, mixed-race descendants of Portuguese and Africans, and poor Portuguese immigrants. In a racially stratified society where landownership and slaveholding were markers of wealth and status, the free poor, especially those who did not possess at least one slave, remained on the margins of society. ${ }^{33}$ Liberal reformers identified them as the object of penal discipline to engender a law-abiding working class. Known as the desprotegidos or the dishonorable poor, they were targeted by the police for recruitment in the navy and army for vagrancy and disorder because of their vulnerable position in the social hierarchy that unfolded from an economy based on slave labor. This was part of the apparatus of security and racialization that characterized port cities, as Brandon has argued in his studies on Paramaribo. ${ }^{34}$

In I 833, sixty galé convicts were relocated from the São José fortress at Snakes Island to Catumby to work on the construction of the Casa de Correção. Given the racial, ethnic, regional, and national diversity of convicts

28. Leila Mezan Algranti, O Feitor Ausente: Estudos Sobre a Escravidão Urbana No Rio de Janeiro, I808-I822 (Rio de Janeiro, I988), pp. 40-55; Luis Carlos Soares, "Urban Slavery in Nineteenth-Century Rio de Janeiro" (Ph.D. dissertation, University of London, 1988); Luis Felipe de Alencastro, "Prolétaires et Esclaves: Immigrés Portugais et Captifs Africains a Rio de Janeiro, I8 50-1872", Cahiers Du CRIAR, 4 (1984), pp. I $27-137$.

29. Frank, "Layers, Flows and Intersections", p. 3 I 8.

30. Karasch, Slave Life in Rio de Janeiro, pp. 65-66.

31. Algranti, "Slave Crimes", pp. 27-48.

32. Peter Linebaugh and Marcus Rediker, The Many-Headed Hydra: Sailors, Slaves, Commoners, and the Hidden History of the Revolutionary Atlantic (Boston, MA, 2000); Van der Linden, Workers of the World.

33. Karasch, "Rio de Janeiro: From Colonial Town to Imperial Capital”, p. I43.

34. Holloway, Policing Rio de Janeiro, pp. 7-9; Algranti, "Slave Crimes", pp. 31-32; Aufderheide, "Order and Deviance", pp. I4-19; Morgan, Legacy of the Lash, pp. 50-53; Peter Beattie, The Tribute of Blood: Army, Honor, Race, and Nation in Brazil, I864-1945 (Durham, NC, 200I); Pepijn Brandon, "Between the Plantation and the Port", in this Special Issue. 
in the 1830 , the sixty convicts were probably a very heterogeneous group that included mostly slaves but also free people of color, poor white Brazilians, and foreigners. ${ }^{35}$ In the following years, they were joined by prisoners from other worksites. In February I 834, the Director of the Navy Arsenal dispatched convict José da Silva to be employed "in the construction of the Casa de Correção". ${ }^{36}$ It is quite possible that the official was disposing of a troublesome inmate by relocating da Silva from the navy yard in Rio's harbor to Catumby, which was situated at the edge of the city. The convicts would have walked for one hour, chained to one another and under heavy supervision, from the harbor to Catumby. The government had purchased a farm in Catumby that included a two-storied house that served as a jail for the convicts. Catumby was selected owing to its relative distance from the city center and its location at the foot of a hill - Catumby Mountain which the authorities believed would provide the stone and gravel to build the prison. ${ }^{37}$

The utilization of enslaved and legally free prisoners to build the Casa de Correção strategically relocated convicts from Rio's commercial and artisan-owned shop area, where they routinely evaded their dungeons, to the rustic Catumby region. Rio's prisons were notoriously overcrowded and galé convicts were kept aboard hulks in the city's harbor. Aside from the dungeon at Snakes Island and the prison ships, there were three other main jails in the capital: the Aljube, a civil prison; the Calabouço, a dungeon for slaves in custody; and a reformed prison on Santa Barbara Island (Figure 3).

The city's prisons were entrenched in its export economy and in the web of power relations and a social hierarchy that was deeply connected to the plantation and mining economy of its hinterland. Snakes Island, where a dungeon filled with galé convicts was located, served as a station for commercial boats and the prison-hulks. ${ }^{38}$ The Calabouço was situated in a fortress atop Castello Hill at the entrance to the city. The Aljube was imbedded in Rio's slave market in Santa Rita parish in the Valongo, where African slaves first set foot on land after the traumatic voyage across the Atlantic. The Aljube was located in the center of Rio's slave markets, which until I 83 I was at Praia do Valongo. The streets and alleys that spread from the harbor were under close police surveillance because of the economic activities that abounded around the port. Before the construction of the Casa de Correção (in Rua do Conde, Catumby Hill on the map, Figure 3) prisoners were held at the Aljube, the Calabouço, the São José Fortress at Snakes

35. Brasil, Relatório do ministério da justiça do anno I 833 (Rio de Janeiro, I834), pp. I8-I9.

36. Correio Official, 23 February I834, vol. 48.

37. Brasil, Relatório do anno I833, p. I9.

38. J.B. Debret, Voyage Pittoresque et historique au Brésil, ou Séjour d'un Artiste Français an Brésil, depuis I 816 jusqu'en I83 I inclusivement, 3 vols (Paris, I834-I839), II, p. 30. 


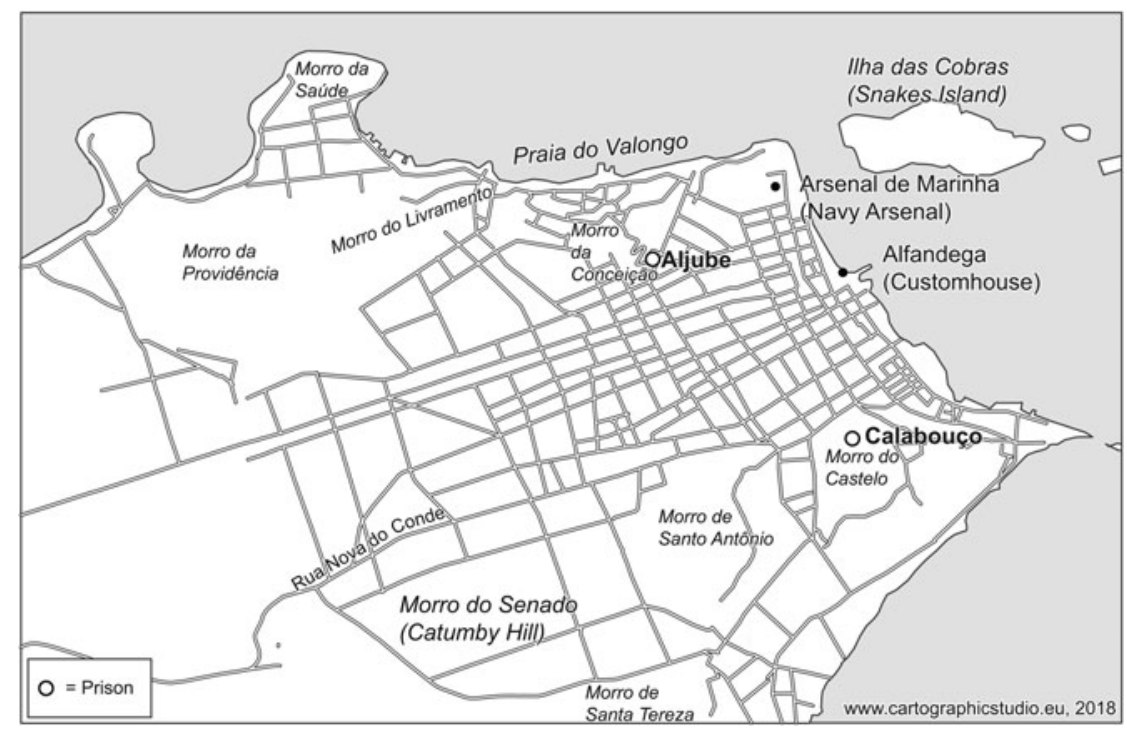

Figure 3. The evolution of Rio de Janeiro from the port region towards its hinterland, with the location of various prison sites.

Island, and the Santa Barbara jail located in the Santa Barbara island off of the Morro da Saúde. The Navy Arsenal near the customhouse was an important $\operatorname{cog}$ in the carceral ring around the port because of its use of conscripted labor, mostly free people of color and liberated Africans. In the I 830 , there were at least two prison hulks - pressiganga - filled with galé convicts, named the Animo Grande and the Não Pedro II. Although the traffic had been abolished in $183 \mathrm{I}$, there were still warehouses in the Valongo where enslaved African men, women, and children were stored before they were sold to the interior. Walking through the straight and narrow streets that extended from the harbor to Catumby and beyond, a foreign visitor to Rio would "continuously encounter convoys of mules which intersected and succeeded one another". ${ }^{39}$ These chains of people and commodities linked the capital to the provinces of Minas Gerais, São Paulo, Goyaz, and Curitiba among others.

The government deployed the need for compulsory labor at the penitentiary to reform its most decrepit dungeons by relieving them of excess residents. Galé inmates were not only sent to work in Catumby, many had their sentences commuted to banishment and were transported to Fernando de Noronha, a penal colony in the north-east, which a mixed slave and legally

39. Debret, Voyage Pittoresque, p. 5 . 
free convict workforce had built. ${ }^{40}$ In December I 834, the African-born slave convicts José Moçambique and João Congo were included in a list of ten prisoners whose sentence to galé was commuted to banishment to Fernando de Noronha. The decision aimed to reduce the "great number of inmates who had accumulated in Rio's prisons at great cost to public finances". ${ }^{41}$ In June I 834, the African-born slaves João Cabinda and José Grande, each sentenced to twenty years of galés, were sent to the Casa de Correção by Rio's Police Chief, along with João Feitor, who had been condemned to thirteen years of "prison with labor". ${ }^{42}$ On 25 June i 834, Eusébio de Queiroz, who served as Police Chief, requested the Commander of the Animo Grande, a prison hulk, to send twenty-four galé convicts to work at the Casa de Correção. ${ }^{43}$

Inmates from the city's jails preferred to be sent to the Casa de Correção because conditions there were much better than at the Aljube or at Santa Barbara Island, which was too distant from the city and afforded them little contact with the mainland, and especially few opportunities for escape. Preference was given to detainees skilled in masonry, carpentry, ditch digging, and others who had demonstrated good behavior. The government considered paying select exemplary inmates a daily wage as an incentive and as a means of control. Other punitive forms of control were necessary. Galés and criminals sentenced to "prison with labor" worked in chains, which controversially blurred the lines between the two groups. The police dispatched prison guards to prevent escapes. ${ }^{44}$ Still, it was not impossible to escape the Casa de Correção. In I 834, Luciano Lira, a convict of free legal status, fled from the worksite. ${ }^{45}$

The relocation of Rio's inmates to the penitentiary also applied to enslaved detainees in custody at the Calabouço. In I 837, I 88 slaves in custody were transferred from the Calabouço at Castello Hill to the Casa de Correção, where they were incarcerated in a new reformed jail, also called Calabouço ${ }^{46}$ In June I 830 , the justice of the peace of Lagoa, a rural parish to the south of the harbor, ordered the detention of the slave woman Theodora at the Calabouço after she was arrested on a farm near Rodrigo de Freitas Lake. ${ }^{47}$ Slave owners regularly brought their bondsmen to the

40. Beattie, Punishment in Paradise, pp. I4-22.

4I. Correio Official, 20 December I 834.

42. Ibid., 2 June 1834 .

43. Ibid., 25 June I 834 .

44. Aureliano de Souza e Oliveira Coutinho to the Brazilian Parliament in Correio Official, 26 May I 834 .

45. Correio Official, 22 March i 834.

46. Ibid., 8 August I 837; Brasil, Relatório do ministério da justiça do anno I 837 (Rio de Janeiro, I 838 ).

47. Diário do Rio de Janeiro, 26 June 1830. 
Calabouço to be flogged for a fee and detained as punishment for disobedience, routine flights, and rebellion. ${ }^{4}$

Slaveholders utilized the Calabouço, before and after its transfer to the Casa de Correção, as a warehouse to contain and correct unruly slaves while negotiating for their sale outside of Rio. It was common to find notices in the city's gazette advertising the sale of slaves like Joaquim, an African from Benguella in West Central Africa, which encouraged interested buyers to visit the Calabouço to inspect them. Joaquim was a skilled blacksmith and compelled his owner to sell him by "refusing to work". ${ }^{49}$ Joaquim Antonio Insua, a petty slave owner who lived in Rio's Valongo, advertised the sale of his Brazilian-born slave, Manoel, a carpenter, under the condition that he was sold "outside of the province". ${ }^{\circ}$

Owners of Calabouço slaves often resided in the city's commercial districts in streets such as Rua do Carmo, where Januario, an enslaved master goldsmith, lived; Castello Street, where the owner of a slave identified as a "good cook" resided; or Fishermen's Street, where the owner of a master tailor, a Brazilian-born slave, resided. ${ }^{5 \mathrm{~T}}$ These notices identified the enslaved by skills, such as cooks, master gilder, apprentice tailors, master tailors, sailors, master goldsmith, carpenters, and barbers. A substantial segment of enslaved detainees were therefore skilled urban slaves. The relocation of the Calabouço to Catumby gave the Casa de Correção access to an enslaved workforce that comprised skilled artisans and semi-skilled slaves, including female slave detainees who worked as cooks and washerwomen. Slave detainees surpassed the number of convicts because they originated from routine police actions and from slave owners who confined them at the Calabouço. The convict population was divided into two groups: minors fourteen years or younger - who were under a correctional regime for vagrancy-related charges, and adult criminals.

The government also deployed the Casa de Correção's construction to reform vagrants and beggars, including delinquent minors under the authority of local justices of the peace. In I 83 I, the Aurora Fluminense commented on a communication from the navy arsenal for mechanics and other skilled workers to present themselves at the armory in order to be hired. The invitation was especially extended to "free or emancipated (liberto) officer technicians", which suggests that free people of color were particularly targeted as the recipients of this policy. ${ }^{52}$ The program "would produce good results

48. Holloway, Policing Rio de Janeiro, pp. $55-58$.

49. Diário do Rio de Janeiro, 2 January 1830.

50. Ibid., i I February I 830.

51. Ibid., 20 March I830, 29 February I830, 24 April I830.

52. Correio Mercantil, 8 June I83 I, also published in Aurora Fluminense, 6 June I83 I; on the utilization of naval labor to control the growing free black population, see Morgan, Legacy of the Lash, pp. 50-5 I. 
by decreasing the number of vagrants who passed through the streets" by disciplining them in the "habit of work". ${ }^{53}$ In I 8 36 , the legislature discussed how to liberate the streets from the "high number of beggars" who harassed residents and considered employing them in their home so that they could provide for themselves. ${ }^{54} \mathrm{~A}$ citizen's letter emphasized that small shops and vendors' stalls maintained by slaves and which specialized in selling groceries and cooked food "provided to the lower classes their means of honest subsistence". However, these places of commerce were unregulated and constituted points of conglomeration for "idlers, drunkards, thieves, gamblers, and ruffians of all caste".55 These preoccupations with vagrancy coalesced in a vigorous police campaign in 1838 to deliver the city of the "infestation" of vagrants, beggars, and their "harmful effects" on society. ${ }^{56}$ The police paid duty officers for each pauper brought to the Casa de Correção, where they were compelled to work on the construction of the prison. A total of 170 vagrants were sent to work at the penitentiary; forty others were sent to the navy. The policy backfired because the Casa de Correção was unable to absorb this surplus labor, which tasked the government's ability to control the prison population. ${ }^{57}$

\section{CONFINEMENT AND THE CHANGING LABOR REGIME OF THE ATLANTIC}

What made the labor arrangement at the Casa de Correção novel compared with previous employment practices in Brazil was its utilization of liberated Africans as involuntary "apprentice" laborers and their distribution to other public institutions and private employers. Convict laborers were an important pillar in Portuguese colonial expansion in Asia, Africa, and Brazil. ${ }^{58}$ European empires traditionally relieved the streets of the burden that a free flowing, unattached vagrant population represented in metropolitan and colonial port cities. ${ }^{59}$ In the Lusophone world, colonial armies and troop

53. Correio Mercantil, 8 June i 83 I.

54. Brasil, Relatório do ministério da justiça do anno I836 (Rio de Janeiro, I837), p. I9.

55. O Chronista, 23 June 1838.

56. Holloway, Policing Rio de Janeiro, pp. I34-1 35 .

57. Thomé Joaquim Rodrigues, Director of the Casa de Correção, to Eusébio de Queiroz Mattoso, Rio's Police Chief, on 2 October i 838, Jornal do Commercio, 6 October 1838.

58. Timothy J. Coates, Convicts and Orphans: Forced and State-Sponsored Colonizers in the Portuguese Empire, I550-1755 (Stanford, CA, 200I), pp. 42-64.

59. Gwenda Morgan and Peter Rushton, Banishment in the Early Atlantic World: Convicts, Rebels and Slaves (London, 2013); Clare Anderson and Hamish Maxwell-Stewart, "Convict Labour and the Western Hemisphere, I4I5-I954", in Robert Aldrich and Kirsten McKenzie (eds), The Routledge History of Western Empires (London, 2013), pp. 102-1 17; Ruth Pike, "Penal Servitude in the Spanish Empire: Presidio Labor in the Eighteenth Century", Hispanic American Historical Review, 58:I (1978), pp. 2 I-40; Timothy J. Coates, Convict Labor in the 
regiments were filled with the unattached and unprotected poor, who expanded the colonial and postcolonial frontier in Brazil. The Casa de Correção's labor scheme therefore constituted an extension of the traditional imperial practice of dragooning unfree people - through the justice system and enslavement - into public work tasks around Rio. The prison's labor scheme was a response to the ripple effects of the changing labor regimes of the Atlantic, from slavery to free labor, by contracting the labor power of liberated Africans for the prison's own use and consigning this commodity to privileged landowners and other public institutions.

"Liberated Africans", known as emancipados in Cuba and "recaptives" in other Atlantic shores, refers to the estimated i I,000 men, women, and children that the Mixed Commission Court in Rio emancipated between I 82 I and $1845 .{ }^{60}$ A subset of that population, I 50 on average, was employed at the Casa de Correção after I 834, when the government authorized the penitentiary to utilize liberated Africans "giving preference to those who were already learning a trade and had shown a love of work". ${ }^{\text {r }}$ As salaried apprentice laborers, liberated Africans represented a significant segment of the prison's workers. Their wages were paid to the government, which acted as a corporate employer when it consigned emancipated Africans to public institutions and to slaveholders. Liberated Africans who worked at the Casa de Correção received a vintém, or ten per cent of their wage, which they could use to buy tobacco and other necessities. The government retained the remainder of their wage for food, clothing, and the cost of confinement. Liberated Africans were also employed at the city's Our Lady of Mercy Charity, the telegraph service, the ironsmith factory in São Paulo province, the light company, and a gunpowder workshop. They were utilized in the repair of Rio's roads, aqueducts, and public fountains, where they worked in a racially mixed workforce of salaried enslaved laborers and legally free workers with skills in carpentry, ditch digging, and masonry.

Portuguese Empire, 1740-1932: Redefining the Empire with Forced Labor and New Imperialism (Leiden, 20I4).

60. This estimate is based on the calculations of Brazilian official Pedro Paulino da Fonseca in I868. He included not only enslaved Africans liberated by the Anglo-Brazilian Mixed Commission between I 82 I and I 845 , but also 4,700 additional Africans emancipated after the Mixed Commission ceased its operations. Paulino da Fonseca estimated the number of liberated Africans in Brazil at I0,700 in I 868. In I 864, Reginaldo Muniz Freire tallied from official registries 7,366 liberated Africans in Brazil, more than 3,000 of whom were liberated after i 845 . See "Estado em que se acham a escripturação da matrícula geral dos diversos carregamentos livres na corte, e provincias do império", Arquivo Nacional do Rio de Janeiro, ANRJ-OI (GIFI) sB-5I9, and ANRJ-ZU Juizo Municipal I era Vara do Rio de Janeiro Maço 646 \# 5473 "Reginaldo Muniz Freire".

6I. See the instructions on the consignation of the labor of free Africans, 29 October I 834, available at: http://legis.senado.gov.br/legislacao/ListaTextoIntegral.action?id=67373; last accessed on 8 November 2016. 
After i 850 liberated Africans employed at the Casa de Correção laid the railroad tracks that connected Rio's harbor to the rural parishes where coffee plantations thrived. The new railroad system symbolized the city's modernization and booming coffee economy.

The legal status of liberated Africans was circumscribed by British and Brazilian laws and the anti-slavery discourse about freedom that linked the Atlantic and the Indian Ocean in the politics of labor exploitation that was inherent to the process of the formation and consolidation of capitalism in the nineteenth century. ${ }^{62}$ Evelyn Jennings's study of road building in nineteenth-century Havana in this volume demonstrates the local and diasporic connections among various systems of regulating unfree labor through apprenticeship which articulated both a liberating labor policy and a recasting of slavery. ${ }^{63}$ The Anglo-Portuguese Treaty of 28 July 18 i 7 instituted the Mixed Commission Court on the African coast and in Rio to adjudicate the legality of slave vessels. The court provided certificates of emancipation to enslaved Africans captured aboard slave vessels and turned the freedmen to local authorities for guardianship to be "employed as servants or free laborers" for fourteen years before being declared "fully free". ${ }^{64}$ The

62. See Robert Edgar Conrad, World of Sorrow: The African Slave Trade to Brazil (Baton Rouge, LA, I986), pp. 56-6I. On the 28 July I 8 I 7 convention, including the regulation of the Mixed Commission, see Lewis Hertslet, A Complete Collection of the Treaties and Conventions, and Reciprocal Regulations, at Present Substituting Between Great Britain and Foreign Powers ... so Far as They Relate to Commerce and Navigation, and to the Repression and Abolition of the Slave Trade, and to the Privileges and Interests of the Subjects of the High Contracting Powers (London, I820), II, pp. 8I-I 23; on the 23 November I 826 treaty, see Hertslet, A Complete Collection (London, I84I), III, pp. 33-35.

63. Tomich, Through the Prism of Slavery, pp. 56-7i; Thomas C. Holt, "The Essence of the Contract: The Articulation of Race, Gender, and Political Economy in British Emancipation Policy, I838-1866", in Frederick Cooper, Thomas C. Holt, and Rebecca Scott (eds), Beyond Slavery: Explorations of Race, Labor, and Citizenship in Postemancipation Societies (Chapel Hill, NC, 2000), pp. 33-59; Ada Ferrer, Freedom's Mirror: Cuba and Haiti in the Age of Revolution (New York, 2014), pp. I2-13.

64. There were courts in, for example, Cuba, Sierra Leone, New York, and South Africa, where liberated Africans were also settled. On the number of emancipados in Cuba, see Inés Roldán de Montaud, "Origen, evolución, y supresión del grupo de negros 'emancipados' en Cuba I 8 17-I870", Revista de Indias, 42:169-170 (1982), pp. 559-64I; also Robert Conrad, "Neither Slave Nor Free: The Emancipados of Brazil, I8 18-1 868", Hispanic American Historical Review, 53:I (1973), pp. 50-73; Edward L. Cox, Free Coloreds in the Slave Societies of St. Kitts and Grenada, I763-I 833 (Knoxville, TN, I984); the latest study on liberated Africans in Brazil is Beatriz Gallotti Mamigonian, "To be a Liberated African in Brazil: Labour and Citizenship in the Nineteenth Century" (Ph.D. dissertation, University of Waterloo, 2002), recently published as Beatriz G. Mamigonian, Africanos Livres: A Abolição Do Tráfico de Escravos No Brasil (São Paulo, 2017). For comparative studies on the experience of free Africans, see Christopher Saunders, "Liberated Africans in Cape Colony in the First Half of the Nineteenth Century", The International Journal of African Historical Studies, I 8:2 (1985), pp. 223-239; Samuël Coghe, "Apprenticeship and the Negotiation of Freedom: The Liberated Africans of the Anglo-Portuguese Mixed Commission in Luanda (I844-1870)", Africana Studia, I4 (2010), 
Portuguese crown promulgated a royal decree in I 8 I 8 that incorporated into Brazilian laws the guidelines of the Mixed Commission and clarified the legal position of liberated Africans in the slave society, including the fourteen-year apprenticeship requirement. ${ }^{65}$

Port cities like Rio were crucial nodal points for articulating and circumscribing the meaning of freedom for liberated Africans due to their significance as doorways for enslaved Africans from the slave trade and the residence of the Mixed Commission courts. The introduction of coffee in the Paraiba Valley had a profound effect on Rio's economy and demography. Coffee cultivation required little technological innovation, but like sugar it thrived on enslaved labor. Enslaved Africans fueled coffee's ascent in Brazil's economy between I83 I and I850 (Figure 4). ${ }^{66}$ Coffee cultivation gave rise to a powerful slaveholding aristocracy whose influence extended to all levels of the Brazilian administrative state, especially after I837, when the rise to power of the Conservative Party marked the end of the liberal era $(1831-1837){ }^{67}$

Eusébio de Queiroz, who called for the discontinuation of slave labor at the Casa de Correção in I849, was an influential member of the Conservative Party. He was well connected to the coffee elite through marriage and was directly in charge of the allocation of "liberated Africans" as free coerced laborers to socially privileged individuals. Queiroz was at the helm of the policy to confine and compel vagrants to work in city projects. He implemented the policy that led to the routine incarceration of free people of color suspected of being fugitive slaves at the Calabouço. ${ }^{68}$ Queiroz's role in the distribution of liberated Africans was an extension of the

pp. 255-273; Rosanne Adderley, “'A Most Useful and Valuable People?' Cultural, Moral and Practical Dilemmas in the Use of Liberated African Labour in the Nineteenth-Century Caribbean", Slavery \& Abolition, 20:I (1999), pp. 59-80; and idem, New Negroes from Africa: Slave Trade Abolition and Free African Settlement in the Nineteenth-Century Caribbean (Bloomington, IN, 2006). For a study of the interconnectedness of the transformation of labor migration in the Atlantic and the Indian Ocean, see Richard B. Allen, "Slaves, Convicts, Abolitionism and the Global Origins of the Post-Emancipation Indentured Labor System", Slavery E Abolition, 35:2 (2014), pp. 328-348; and Clare Anderson, "Convicts and Coolies: Rethinking Indentured Labour in the Nineteenth Century”, Slavery E Abolition, 30: I (2009), pp. 93-109.

65. Robert Edgar Conrad, Children of God's Fire: A Documentary History of Black Slavery in Brazil (Princeton, NJ, I 994), pp. 332-333; on the I 83 I law, available at: http://www2.camara.leg.br/legin/ fed/lei_sn/r 824-I 899/lei-37659-7-novembro-I 83 I-564776-publicacaooriginal-88704-pl.html; last accessed 26 October 2018.

66. Stanley J. Stein, Vassouras: A Brazilian Coffee County, 1850-1900: The Roles of Planter and Slave in a Plantation Society (Princeton, NJ, 1986).

67. Jeffrey Needell, The Party of Order: The Conservatives, the State, and Slavery in the Brazilian Monarchy, I83I-I87I (Stanford, CA, 2006).

68. Sidney Chalhoub, "The Precariousness of Freedom in a Slave Society (Brazil in the Nineteenth Century)", International Review of Social History, 56:3 (201 I), pp. 405-439. 


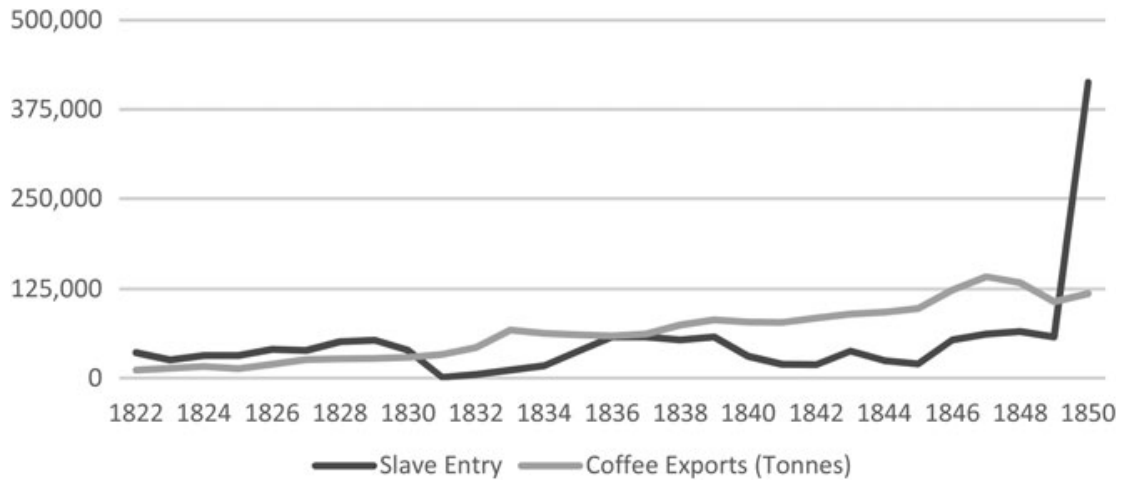

Figure 4. Brazilian Coffee Exports and the Traffic in Slaves, I 822-1850.

Corrected statistics for the volume of commodity exports from Brazil are taken from Christopher David Absell, "Brazilian Export Growth and Divergence in the Tropics during the Nineteenth-Century", IFCS - Working Papers in Economic History, WH, May 20I5, pp. I4I. Data on the volume of the slave trade originate from the Trans-Atlantic Slave Trade Database, available at: http://wrwro.slavevoyages.org/; last accessed 26 October 2018.

conservative strategy to identify people of color - enslaved and free - as slaves unless proven free, but also part of a broader process of statecraft that involved establishing the rule of law in the policing of the illegal slave trade. ${ }^{69}$ Coffee's rise as Brazil's chief agrarian export corresponded with the expansion of the illegal traffic and a crucial period of postcolonial state formation. A 7 November I 83 I law abolished the traffic, branded traffickers as pirates, and criminalized their activities. The law recommended repatriating liberated Africans to their homeland, which represented an important legal departure from British abolitionist policies because it did not envision incorporating emancipated Africans as "apprentices of freedom" in Brazilian society. ${ }^{70}$ Liberal legislators who supported the I 83 I law viewed the slave trade as a problem for postcolonial nation-building and advocated slavery's gradual abolition while building the penitentiary to discipline the free poor into workers. They viewed the entry of new Africans as introducing an "internal enemy" into Brazil that was incompatible with progress. $^{71}$

69. See Registro da correspondencia da maior importancia de Euzébio Q. C. M. da Camara, quando Chefe da Polícia da Corte, I833-1850, AN, Códice 1004, vol. I.

70. Jennifer Nelson, "Apprentices of Freedom: Atlantic Histories of the Africanos Livres in Mid-Nineteenth Century Rio de Janeiro", Itinerario, 39:2 (2015), pp. 349-369.

7I. For a study on anti-slavery ideas in the first half of the nineteenth century, see Jaime Rodrigues, O Infame Comercio: Propostas e Experiencias No Final Do Trafico de Africanos Para o Brasil (I800-I850) (Campinas, 2000). 


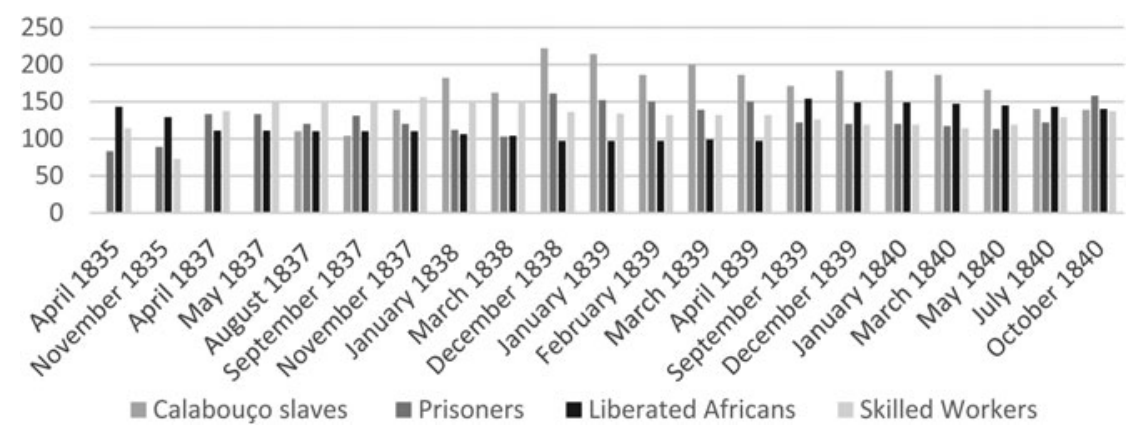

Figure 5. Slaves, Convicts, Liberated Africans, and Skilled Workers at the Casa de Correção, I $835-1840$.

Compiled from the monthly reports on the prison's workforce. "Relatório dos Trabalhadores $e$ Operários Empregados nas Obras da Casa de Correção", in Diário do Rio de Janeiro, O Despertador, Correio Official, I835-I840.

The general consensus among liberals and conservatives was that Brazil constituted a territory of slavery for Africans. ${ }^{72}$ At best, radical politicians believed that it was dangerous for liberated Africans to remain in Brazil because they would be immediately re-enslaved and sold to the interior. ${ }^{73}$ Indeed, gangs of thieves often attacked the slave vessels which were anchored in Rio's harbor, filled with enslaved Africans during the adjudication process. ${ }^{74}$ Studies on the Emilia and the Brilhante, two slave vessels captured in $182 \mathrm{I}$ and $\mathrm{I} 842$ respectively, show that confinement aboard these ships and at the Casa de Correção constituted an important period of identity formation for the captives and transfer of diasporic knowledge about slavery and freedom. Slaves aboard the Brilhante primarily spoke Kimbundu forty per cent of the captives - and could therefore converse with one another about the trauma of enslavement, the middle passage, and the emancipation process. The other slaves spoke Bantu languages but were not isolated. Likewise, slaves from the Emilia were of Congo-Angolan origins and were able to establish close, interpersonal relationships that allowed them to make sense of the social, economic, and political underpinnings of Rio's port society and to deploy strategies of resistance and survival. The

72. See the discussions on the Barbacena Bill to revoke the I83 I law in Conrad, World of Sorrow, pp. 92-97; Sidney Chalhoub, "Illegal Enslavement and the Precariousness of Freedom in Nineteenth-Century Brazil", John D. Garrigus and Christopher Morris (eds), Assumed Identities: The Meanings of Race in the Atlantic World (Austin, TX, 2010), pp. 88-I I 5.

73. Justice Minister Diogo Antonio Feijó in Relatório do anno I 83 I (Rio de Janeiro, I 832), p. 6. 74. Beginning in February I 834, the government began to relocate illegally enslaved Africans from land seizures to the Casa de Correção. See, AN, Códice I,004, Vol. I and Códice 399. The first group of liberated Africans from ship confiscation to be sent to the prison originated from the Duquesa de Bragança and the Santo Antonio slavers which were sentenced in July I 834 . 
records of the Brilhante and other captured slave ships in Cuba and Freetown reveal that families often experienced the traffic, adjudication, and confinement together, though they were eventually separated once distributed to private employers. ${ }^{75}$ The mortality rate among enslaved Africans who awaited the decision of the Mixed Commission was very high. The necessity to prevent their re-enslavement, reduce their mortality, and ultimately the failure to repatriate them led to their confinement at the Casa de Correção in depósito or under legal guardianship. ${ }^{76}$ Confinement became a formative regulatory aspect of the emancipation process for liberated Africans, while also entrenching slavery through the incarceration of rebellious slave detainees.

Liberated Africans were held at the Casa de Correção because they were a symbolically dangerous group in the slave society. In i 834, Manoel Alves Branco, a government minister, admitted that "it was still not possible to re-export any of the liberated Africans out of the empire". As a result, he argued, the government "was forced to distribute" them to privileged employers based on the I 8 I 8 decree which authorized utilizing them in public works. ${ }^{77}$ It was inconceivable that liberated Africans could be released into the Brazilian population as "free men" as Branco acknowledged that "even their distribution did not satisfy the great purpose of ridding the country of an ever dangerous population" ${ }^{78}$ Branco's statements expressed the ambivalence of the Brazilian authorities about the politics of regulating the presence of liberated Africans. Even as the government distributed liberated Africans to politically connected civil servants, officials expressed the fear that this population could introduce subversive ideas among the slave population, a great number of whom were illegally enslaved after i83i. The

75. Nelson, "Apprentices of Freedom”, pp. 350-356; Walter Hawthorne, “Being Now, as it Were, One Family': Shipmate Bonding on the Slave Vessel Emilia, in Rio de Janeiro and Throughout the Atlantic World", Luso-Brazilian Review, 45:I (2008), pp. 53-77; Daniel Domingues da Silva et al., "The Diaspora of Africans Liberated from Slave Ships in the Nineteenth Century", The Journal of African History, 55:3 (2014), pp. 347-369.

76. Depósito was an Iberian practice to protect vulnerable groups and was used in colonial times to regulate the honor of women who divorced their husbands or to protect slaves petitioning crown authorities against their masters on the grounds of excessive use of violence. I interpret depósito - known as recogimiento in the Spanish Atlantic - as confinement because in practice liberated Africans did not receive the legal protections that the term implied; on women and guardianship, see Nancy van Deusen, "Determining the Boundaries of Virtue: The Discourse of Recogimiento among Women in Seventeenth-Century Lima", The Journal of Family History, 22:4 (1997), pp. 373-389; on enslaved Africans placed into government custody, see Sherwin Bryant, "Enslaved Rebels, Fugitives, and Litigants: The Resistance Continuum in Colonial Quito", Colonial Latin American Review, I3:I (2004), pp. 7-46.

77. The government issued two instructions in I 834 and I 835 authorizing the employment of liberated Africans. See Mamigonian, "To Be a Liberated African in Brazil”.

78. My emphasis. Minister Manoel Alves Branco, Relatório do anno I 834 (Rio de Janeiro, I 835), p. 8. 
authorities feared that the consignment of liberated Africans could "become unbearable after they have become acculturated and circulating with the opinion of free men among slaves". ${ }^{79}$ In the aftermath of the Haitian Revolution and the Malê/Muslim slave rebellion in Bahia, liberated Africans appeared as a particularly incendiary group. In I835, Paulino Limpo de Abreu, another government minister, published a letter in which he raised the specter that the Bahian insurgency would expand to Rio due to its "territorial proximity" to Salvador and "the size of its slave population". Abreu understood that it was Rio's standing as a seaport which made it susceptible to the spread of the rebellion from the north-east. In the 1830 , mutinies by troop regiments in the north-east spread through Rio from the sea through navy sailors and mariners who traveled between the two cities and carried the wind of insurgency with them. Abreu argued that it was the "impolitic conservation of liberated Africans among us" that raised the alarm. There existed "secret societies", he continued, "which worked systematically to foment slave insurrections by preaching the Haitian doctrine of a mass slave uprising". ${ }^{8}$ The idea of freedom that liberated Africans and Haiti symbolized was regarded as a colossal threat to the expansion of slavery in the coffee region.

Small-scale slave owners and Rio residents also expressed a fear of the ideological powder keg that liberated Africans represented on the streets. A resident who identified as a "victim" implored Police Chief Eusébio de Queiroz to continue the "wise measures to cleanse the city" of liberated Africans. The author argued that liberated Africans were "harmful" to the slave order and concluded that most emancipated Africans were "corrupt and seduced slaves" into freedom "by taking them to their residences". ${ }^{8 \mathrm{I}}$ The persistence of the Brazilian authorities in referring to liberated Africans as "Africanos livres", which literally translates as "free Africans", offers an interesting window onto the ambivalence of slavery's expansion in the nineteenth century. The term "Africanos livres" distinguished liberated Africans from other African-born slaves who had been manumitted by their owners or freed through self-purchase and were known as "Africanos libertos", or emancipated Africans. The persistence of the term "Africanos livres" in Brazil, where the "second slavery" expanded most massively in the nineteenth century, points to the conflicting politics of liberation and unfreedom that defined the labor landscape of the Atlantic. The Casa de Correção was a key site for articulating this process because of its significance as employer and distributor of liberated Africans as well as its significance as a penitentiary.

79. Ibid.

80. Correio Official, 30 March I835, \# 70; on the Malê rebellion, see João José Réis, Slave Rebellion in Brazil: The Muslim Uprising of I835 in Babia, trans Arthur Brakel (Baltimore, MD, 1995).

8. Diário do Rio de Janeiro, Io December I 839. 


\section{THE MOTLEY CREW}

In total, 450 to 700 slave detainees, free prisoners, leased slaves and free craftsmen, vagrants, and liberated Africans built the original pavilion of the Casa de Correção between I834 and I850. Workers carried the stone to erect the tall walls that sealed the prison from the city and dug into the hard clay ground of Catumby Hill to build the penitentiary's foundations. It was grueling work. The government hired a company to provide the food and clothing for the prison's residents and builders. Though most prisoners were men, there were many women who contributed to the prison's construction as cooks and seamstresses after i 850 .

The authorities established a hierarchy among the workers according to skills and legal status. Skilled workers were recorded separately in monthly reports on the prison's workforce. There were on average 54 stonemasons, I 5 carpenters, 4 cart pushers, I 7 stone cutters, I to 2 cooks, I overseer, and 6 or 7 foremen among the skilled laborers. Skilled craftsmen were a mixture of leased slaves, Calabouço slaves, convicts of legally free status, and hired skilled craftsmen of Portuguese descent. Skilled craftsmen included individuals like Manoel José Soares, an immigrant from Trás-os-Montes in north-eastern Portugal who arrived in Rio de Janeiro in May i 836. By I 838, he was employed as a stonemason at the Casa de Correção. He lived in Conde Street, in the immediate proximity of the prison. In I 835 , IOI laborers identified as "craftsmen and apprentices of various trade" worked at the prison without clarification of their legal status, which suggests that this information was not important to the authorities in categorizing the workforce. But in I 849, when Eusébio de Queiroz became concerned with reforming the prison's labor force, he observed that salaried day workers "were almost all slaves, especially in the class of stonemasons". ${ }^{2} \mathrm{He}$ calculated that nineteen out of twenty stonemasons and sixteen out of twentyseven ditch diggers were slaves.

Skilled workers also included liberated Africans as apprentices and as experienced craftsmen. It is possible that liberated Africans were already skilled artisans when they arrived in Brazil, and that they were transferring manual skillsets to the new environment. But the discourse of "apprentices of freedom" that regimented the lives of liberated Africans at the Casa de Correção shaped official perceptions of emancipados as unskilled workers who "showed more devotion and skills" than other laborers at the penitentiary. ${ }^{83}$ Prison administrators highlighted the docility of liberated Africans and their eagerness to be trained as craftsmen to indicate the success of apprenticeship. By claiming that liberated Africans were dutifully learning

82. Brasil, Relatório do anno I849 i A, p. 53.

83. Justice Minister Antonio Paulino de Abreu, Relatório do anno I 836 (Rio de Janeiro, I 837), pp. 27-29. 
a trade, the authorities could justify the benefits of utilizing them to build the prison while implicitly comparing them with the idle Brazilian vagrants.

Portuguese nationals were employed in managerial positions as foremen and overseers. Slave plantations routinely utilized Portuguese men as overseers, which allowed planters to deflect the violence of the slave regime to those who enforced the power of the whip. Portuguese overseers were known to be particularly violent. They often received the brunt of slaves' violence against enslavement. ${ }^{84}$ By hiring Portuguese men as overseers, prison administrators recreated the racial and ethnic dynamic of the plantation at the Casa de Correção. Still, by having Portuguese supervisors and foremen work alongside other skilled workers, leased slaves, Brazilian nationals, convicts, and other Portuguese craftsmen, administrators deftly identified them as one undifferentiated group (Table 2). This strategy reinforced hierarchies of control through the manipulation of ethnic difference, legal status, and the infamous tensions between Brazilians and Portuguese subjects.

Tensions between Portuguese overseers and enslaved Africans exploded in the most famous case of resistance at the Casa de Correção, which involved a Congo-born liberated African, Bonifácio, who killed a Portuguese supervisor, Joaquim Lucas Ribeiro, in I 846 . Ribeiro was scheduled to publicly chastise Bonifácio with a palmatória, a flat wooden instrument traditionally utilized to castigate domestic slaves. The authorities usually flogged Calabouço slaves between noon and $2.00 \mathrm{pm}$ in the presence of their masters, who paid the government for the service. Bonifácio would have understood the lashing in the presence of slave owners as particularly degrading. When Ribeiro approached Bonifácio, the latter repeatedly struck the supervisor in the chest with a compass. At his trial, Bonifácio argued that "he had lost his mind" "because of the punishments that he had received and would still suffer" from Ribeiro. Surprisingly, Bonifácio was sentenced to only a year of "prison with labor", which suggests that the jurors did not really sympathize with Ribeiro. Despite the overseer's authority over the liberated African, he was still a disposable worker. ${ }^{85}$

Resistance at the prison took the form of grievances to improve treatment of workers and convicts but did not challenge its labor arrangement, as is apparent from an I84I petition that legally free prisoners and liberated Africans wrote to the emperor. ${ }^{86}$ The petition was divided into two sections that addressed the complaints of each group separately; this suggests that convicts and liberated Africans recognized their common experience as a

84. Bryan McCann, “The Whip and the Watch: Overseers in the Paraíba Valley, Brazil”, Slavery E Abolition, i 8:2 (1997), pp. 30-47.

85. Gazeta dos Tribunaes (RJ), 30 June I 846.

86. Nelson, "Apprentices of Freedom”, pp. 350-362, and Hawthorne, "Being Now, as it Were, One Family", pp. 53-77. 
Table 2. Casa de Correção's workforce by skills and status, March 1838.

\begin{tabular}{lrrr}
\hline Stonemasons & 54 & Correctional and criminal inmates & 103 \\
Carpenters & 15 & Liberated Africans employed by the CC & 104 \\
Stonecutters/ & 17 & Calabouço slaves & 162 \\
$\quad$ Cavouqueiros & 7 & Liberated Africans in depósito & 18 \\
Foremen & 1 & Liberated African employees from other & - \\
Overseer/Apontador & 52 & institutions & \\
Canteiro & 4 & & \\
Cart pushers (Carreiros) & 1 & 387 \\
Blacksmith (Serralheiro) & 1 & \\
Cook & 2 & \\
Cell keyholders & 154 & \\
Total & &
\end{tabular}

Sources: "Relação dos Trabalhadores e Operários Empregados nas Obras da Casa de Correção em o mez de Março 1838", in Correio Official, 6 June 1835. The administrative staff are not listed in this table. They included a surgeon, a nurse, a clerk, a guarda de obra (general supervisor), a chief administrator, a prison warden, a doorman at the main gate, and a supply collector or arrecadador.

confined population whose labor was vital for building the penitentiary despite their different legal status. Legally free prisoners pleaded with the emperor to "listen with compassion to their complaints and sufferings". They argued that the construction of the penitentiary, the navy arsenal, and "all other public works" in the city were important nation-building projects to which they contributed. They denounced the unequal treatment in the quality of food and clothing of convict workers at the Casa de Correção and at the navy arsenal. Their discussion of unjust treatment in the distribution and the quality of food and clothing articulated claims of citizenship that were based on the language of imperial paternalism. The letter denounced rampant corruption among prison administrators. Convicts criticized the administrative staff as primarily Portuguese and the prison population as mostly Brazilians. The petition reminded the emperor, who was born in Brazil, of the well-known "bitter rivalry between Portuguese and Brazilians" and argued that the predominance of Portuguese in the administrative staffs would eventually "lead to violence" ${ }^{87}$ Bonifácio's killing of the overseer in 1846 dramatically fulfilled this prediction.

Liberated Africans took turns to beseech the emperor to look toward the "poor black Africans", who labored in public works in the city and sought "relief" from their sufferings at the Casa de Correção. They referred to

87. "Requerimento dos presos sentenciados a serviço da Casa de Correção a S.M.I. relatando a insuportável situação a que eram submetidos pelo administrador daquela casa e pedindo providências que lhes permitissem viver com dignidade”, 2 March I84I, Manuscript, Biblioteca Nacional, RJ, II-34, 25 , o I I. 
themselves as "slaves", but it was a strategic identification to gain the emperor's sympathy because slave detainees from the Calabouço were not included in the petition. The petitioners deployed the term to qualify their real lived experience and treatment at the prison and to alert the emperor to their plight. Liberated Africans also identified themselves as contributing members of society who supported the larger project of modernizing Brazil through their labor. They argued that prison administrators deprived them of some basic privileges - customary rights - that distinguished them from slave detainees at the Casa de Correção, such as the privilege to walk around the small garden plot at the prison on Sundays and saints' days. They were forced to live in the Calabouço with slave detainees and were kept in their cells on holy days. Even their vintém - partial wage - was withheld at times as punishment. The emancipados were therefore arguing that they were treated no better than slaves and convicts. They expected the emperor to know that they were neither slaves nor convicts but apprenticed laborers and freedmen. The petition also addressed the suffering of liberated African women - and one might imagine children - at the Casa de Correção. One liberated African woman was "castigated so vigorously" that her clothes ripped apart. She was subsequently sent to work in the chained water gang despite her wounds. The emancipated Africans asked the emperor to remove their "iron chains" and to relocate them to the navy arsenal. Their request is significant because in the I 840 s naval officers began reforming the navy arsenal's workforce by replacing slave workers with free wage laborers, part of the politics to discipline the growing free black population in the city by impressing them into the navy, where corporal punishment was applied to sailors until the first decade of the twentieth century. ${ }^{88}$ In November I 840 , the administrator of the navy arsenal published a notice stating that the office would hire only "legally free craftsmen". ${ }^{89}$ In September I 840 , the armory "dismissed all slave craftsmen" and decided to "admit only free artisans", including those as sailors and operators of machinery. ${ }^{\circ}$ Liberated Africans knew that the law had declared them free, and those who worked at the Casa de Correção were well cognizant of labor conditions at the arsenal. It is therefore possible that their request to be relocated to the navy arsenal was an attempt to claim "full freedom" as free blacks despite the precariousness of that position. ${ }^{9^{\mathrm{I}}}$

88. Morgan, Legacy of the Lash, pp. 50-53.

89. Diário do Rio de Janeiro, Io November I 840.

90. Ibid., 23 September 1840.

91. Beatriz Gallotti Mamigonian, "Conflicts over the Meanings of Freedom: The Liberated Africans' Struggle for Final Emancipation in Brazil, I840s-I860s”, in R. Brana-Shute and R.J. Sparks (eds), Paths to Freedom: Manumission in the Atlantic World (Columbia, SC, 2009), pp. $235-264$. 


\section{FROM SLAVERY TO FREE LABOR}

On 7 July I 850 , the Casa de Correção was inaugurated after sixteen years of construction under Eusébio de Queiroz's leadership. Queiroz hoped that inaugurating the penitentiary would finalize the process of sanitizing the city's prisons, especially following a devastating epidemic of yellow fever in I 849 that many linked to the city's crowded jails and the presence of slave vessels in its harbor. Queiroz observed that there was a "superabundance of labor" at the Casa de Correção and suggested discontinuing the utilization of enslaved workers and replacing the penitentiary's mixed slave and legally free workforce with free wage workers..$^{92}$ Effectively, in January I 849 , Queiroz fired all wage-earning slaves and sent a call to hire only legally free workers to work at the penitentiary. He justified this decision by arguing that free workers "competed in more than sufficient numbers" for work in the city. ${ }^{93}$ Queiroz concluded that the labor of leased slaves was inferior to that of legally free wage laborers and asserted that the difference between legally free workers and leased slaves was the "contrast between one who toiled for himself" and "one who labored for others". Queiroz's assessment was based on his knowledge that it was the masters of the leased slaves who pocketed their wages. Leased slaves therefore had no incentive to improve their performance and productivity.

Queiroz's opportunistically timely appreciation of free wage laborers was the result of his involvement in managing the "abolition crisis" that resulted from the cessation of the traffic between I 848 and I $850 .{ }^{94}$ In I 845 , the British Parliament passed the Aberdeen Act, which empowered cruisers to confiscate Brazilian ships to curtail the slave trade. The act challenged Brazilian sovereignty and culminated in the abolition of the traffic in I850 with the passage of the Eusébio de Queiroz Law. The Brazilian government actively policed its coasts to enforce the law and a few slave ships were captured as late as I $856.9^{95}$ Reflecting on the events leading to the 1850 law, one justice minister argued that the illegal entry of millions of Africans into Brazil demonstrated that the country had failed to "execute effectively its laws" and "the imperial government" had to "bring about the complete extinction of the

92. Brasil, Relatório do anno I849, IA, p. 53.

93. Ibid.

94. Slaves continued to arrive in Rio until as late as I 854 ; for a revisionist perspective on abolition that attributes it to slave resistance, see Dale Graden, “An Act 'Even of Public Security': Slave Resistance, Social Tensions, and the End of the International Slave Trade to Brazil, I 835 -1 836 ", Hispanic American Historical Review, 76:2 (1996), pp. 249-282; Sidney Chalhoub, "The Politics of Disease Control: Yellow Fever and Race in Nineteenth-Century Rio de Janeiro", Journal of Latin American Studies, $25: 3$ (1993), pp. 44 I-443. Classic interpretations of the cessation of the traffic privilege the effects of British pressure on Brazil. See Leslie Bethell, The Abolition of the Brazilian Slave Trade: Britain, Brazil and the Slave Trade Question (Cambridge, 1970), and Conrad, World of Sorrow.

95. Bethell, The Abolition of the Brazilian Slave Trade, pp. 327-359. 
traffic as a measure of social convenience, civilization, national honor, and even of public security". ${ }^{6}$ The reference to public security was an allusion to the problem that the expansion of slavery represented in Brazil, while it was ideologically challenged in the aftermath of the Haitian Revolution. ${ }^{97}$ Brazilian slave owners had fashioned the postcolonial state to protect the continuation of the traffic through draconian laws that inflicted severe punishment on slave rebels, including the death penalty. ${ }^{9}$ Politicians continuously feared the implications of the predominance of Africans in the slave population, even as they asserted the necessity of slaves for national economic production. Seaports like Rio were under particular vigilance because, as one minister argued regarding the challenge of controlling urban slaves, "one does not guard this property, it walks through the streets". 99 Salvador's Police Chief established an $8.00 \mathrm{pm}$ curfew to restrict the circulation of slaves and freed persons in the city after the I 835 Muslim uprising. ${ }^{100}$ Powerful police forces were created in Rio, Salvador, and São Paulo to control their expanding urban slave population and acted as the "coercive power of the owner class" in these settings. ${ }^{101}$ Queiroz oversaw the formation of Rio's police between I 833 and I 840 . As Justice Minister in I 848 , he administered the maintenance of public security in the empire and was at the heart of the diplomatic firestorm occasioned by the Aberdeen Act. On 4 September I 850 , two months after the opening of the Casa de Correção, he promulgated the Eusébio de Queiroz Law, which authorized Brazilian authorities to apprehend all vessels caught with slaves aboard or with signs of involvement in the traffic. ${ }^{102}$ The law stipulated that Africans freed from the traffic would be repatriated to their ports of origin on the African coast or "anywhere outside the Empire". The i 850 law closed a loophole in the I83 I regulation by specifying that liberated Africans who were not repatriated would be put to work under the "guardianship of the government" but not consigned to private employers. However, the utilization of liberated Africans as involuntary free laborers continued until their emancipation in 1864 . By then, the

96. Minister of Justice José Idelfonso de Sousa Ramos to President of the Province of Rio de Janeiro Luis Pedreira do Couto Ferraz on the Eusébio de Queiroz Law, quoted in Graden, "An Act 'Even of Public Security", p. 249.

97. Graden, “An Act 'Even of Public Security”, pp. 249-25 I; Ferrer, Freedom's Mirror, pp. 48-49. 98. Needell, The Party of Order, pp. I I0-1 16 and I33-137; Brown, "A Black Mark on our Legislation"”, pp. 95-I 2 I; Ribeiro, "No meio das galinhas as baratas não têm razão", pp. 43-67. 99. Justice Minister Diogo Feijó in Relatório do anno I833, p. 24.

Iо०. Graden, “An Act 'Even of Public Security”, p. 264.

ıо . Holloway, Policing Rio de Janeiro, pp. i I4-i I s.

I02. Law 58 I of 4 September I 850, available at: http://www.planalto.gov.br/ccivil_03/leis/LIM/ LIM58r.htm; last accessed 7 May 2016. On Eusébio de Queiroz's political biography and the Conservative Party, see Vainfas Ronaldo (ed.), Dicionario do Brasil Imperial (I822-I889) (Rio de Janeiro, 2002), pp. 245-246 and I66-168. On Queiroz's influence on policing Rio, see Holloway, Policing Rio de Janeiro, pp. 103-105. 
government had already lost count of how many liberated Africans had been distributed, and to whom.

As the author of the I 850 law and the person in charge of public security in the empire, Queiroz had a keen understanding of the implications of the regulation for the continuation of slavery in Brazil. Without the continuous entry of African slaves, the production of coffee and sugar, the basis of national wealth, would decline. Queiroz, a slaveholder and a politician, contextualized his call to cease hiring leased slaves at the Casa de Correção as part of a policy to redirect slaves to plantation agriculture in rural zones for the preservation of slavery. He justified his forceful intervention in the Casa de Correção's workforce by arguing that "national interests called for the need to protect colonization and reduce the criminal introduction of slaves". Queiroz's reference to the traffic as "criminal" expressed the consensus among politicians in Brazil's important port cities, Rio, Salvador, São Paulo, that the significance of African slaves in the Brazilian population occasioned by the traffic posed a constant threat of violent slave uprisings. They were ever conscious of the reality that the slave vessel was the "material infrastructure" that renewed slave labor in Brazil while serving as the vehicle of "revolutionary antislavery" ${ }^{103}$ In 1848 , the provincial assembly of Bahia in the north-east passed a law which prohibited African slaves and freedmen from being employed as sailors, a recognition that the seaport was the seedbed for the entry of subversive ideas. The city's merchants went so far as to purchase 185 boats, which they offered to legally free Bahians to replace the African sailors. ${ }^{104}$

Queiroz understood that the abolition of the traffic necessitated a shift in the geography of slavery from coastal towns and busy port cities to the country's agrarian hinterland, where slave labor was most needed. He initiated that process at the Casa de Correção, not necessarily as a precursor of a foreordained abolition of slavery but as part of the politics of permutations of free and unfree labor from which Brazilian colonization and postcolonial state formation unfolded. Effectively after I 849, there were numerous calls to hire skilled artisans to work at the Casa de Correção, such as a call for ax carpenters, two master blacksmith, two shoemakers, and a tinsmith. ${ }^{\text {Ios }}$ These new employees worked as instructors in the prison's workshops, initiating its transition into a reformatory penal institution to produce a disciplined citizenry. Liberated Africans continued to contribute to build the second pavilion of the penitentiary, which was completed in 1860 . However, waged slaves disappeared from the prison's workforce, a fact which signified their exclusion from the city's labor market.

I03. Ferrer, Freedom's Mirror, p. 58.

I04. Graden, "An Act 'Even of Public Security”, p. 268.

105. Diário do Rio de Janeiro, ig August I852. 
Slaves continued to shape Rio's economic life, but their numbers dwindled from thirty-eight per cent in I 849 to less than seventeen per cent of the city's residents by i 872 . Most of the shift occurred among male slaves, the number of whom diminished by sixty-two per cent. The city's slaves, especially enslaved male workers, were being sold into Rio's hinterland to work in agriculture. The redistribution of the slave population from the north-east to the central-south region, and from coastal cities to the agrarian hinterlands, was a political process of managing the ripple effects of the cessation of the traffic to preserve slave labor for as long as possible in Brazil. The drop in Rio's male slaves corresponded with an upsurge of I I 3.3 per cent in the number of male Portuguese immigrants, an increase that started in I849 and that facilitated the displacement of slaves as wage laborers from Rio's market to the countryside. ${ }^{\mathrm{I} 6}$ Portuguese immigration led to an expansion of free and foreign-born workers in the city and became associated with free wage labor. Lusophone immigrants eventually eclipsed slaves-for-hire in Rio's free-market economy. ${ }^{107}$ Foreigners who joined the ranks of the free poor began taking occupations previously held by wage-earning slaves, such as carrying water in the city. The government modernized the business of carrying weights by encouraging immigrants to utilize wheeled carts, which were more efficient. The cessation of salaried slave labor at the Casa de Correção was, therefore, consistent with a broader process in which free wage workers began to substitute salaried slave laborers in Rio de Janeiro.

\section{CONCLUSION}

This story of the utilization of a mixed labor force to build the Casa de Correção between I 834 and I 850 demonstrates that port cities such as Rio were key nodal points from which to examine the relations between free and unfree labor in the Age of Abolitionism globally and postcolonial state formation in Latin America specifically. As Brazil's capital city and its most significant seaport, Rio became the experimenting ground for modernizing institutions of social control which were vital for securing the flow of people - slaves and immigrants - as labor commodities of the Atlantic to and from its hinterland. The government organized a labor force from the city's enslaved and legally free population to build the prison. Legally free individuals were also reduced to unfreedom through imprisonment and coerced labor, including navy and military labor, as Megan Thomas has argued, to erect the penitentiary and maintain order on the streets. The flexibility and opportunism that this labor practice evidenced highlights the underbelly of global capitalism and postcolonial state formation during a crucial period

106. Ibid.

107. Alencastro, "Prolétaires et Esclaves", pp. I33-136. 
in which anti-slavery currents challenged chattel slavery in the Atlantic while convictism mobilized mass labor in the Indian Ocean. ${ }^{108}$ The reorganization of the Casa de Correção's labor force after i 850 did not signify a termination of slave labor in Brazil, but rather its entrenchment in the coffee plantations of the hinterland until abolition in I 888. Slaves continued to inhabit the penitentiary's cells - notably at the Calabouço - for disobedience or for flight while legally free vagrants and criminals toiled in its workshops to inculcate in them the appreciation of work. 